\title{
Counterspace
}

\section{Pandemic paranoia: Toward a reparative practice of the global psyche}

\author{
Wen Liu (1) \\ Institute of Ethnology, Academia Sinica, No. 128, Sec. 2, Academia Rd, Nangang \\ Dist., Taipei City 115, Taiwan. \\ E-mail: wenliu@gate.sinica.edu.tw
}

\begin{abstract}
The COVID-19 pandemic has produced a collective paranoia which is not only driven by our psychic anxiety but also mirrors the irrationality of the crisis and the failure of global governance. During such catastrophic times, in which the state has failed to create a sustainable civil society, scholars such as Melanie Klein, Silvan Tomkins, and Eve Sedgwick have theorized the ways in which we may turn paranoia away from its destructive tendency toward a reparative practice of relationship-building and collective action. I discuss the limits of a clinical approach to paranoia and propose a reparative practice of the global psyche toward social transformation, especially in relation to the rise of anti-Asian violence during the pandemic.

Psychoanalysis, Culture \& Society (2021) 26, 608-622. https://doi.org/10.1057/ s41282-021-00236-2; published online 29 September 2021
\end{abstract}

Keywords: paranoia; affect theory; queer theory; critical psychology; reparative practice; Asian Americans

The global outbreak of COVID-19 has made various populations prone to paranoid affect. For those of us living in the United States, paranoia is not only a conspiracy theory that circulates on social media but also an everyday reality. The exponential growth of infected cases, federal warnings regarding the shortage of hospital beds and medical supplies, and rapidly changing quarantine and lockdown policies - i.e. a state of exception without a foreseeable end - have become the daily routine of many residents. As Anthony Fauci, the director of the National Institute of Allergy and Infectious Diseases, said in an interview in March 2020 when the outbreak started, "If it looks like you're overreacting, you're probably doing the right 
thing” (Budryk, 2020). The neoliberal precarity of the privatized health system, the heightened state of surveillance, and the uncertainty surrounding the pandemic's prognosis breed paranoia. Because the nation-state is incapable of sufficiently addressing the crisis at hand, we find ourselves absorbed in unanswered panic: How do we know whether we are infected? Is the test accurate? Is the government withholding the statistics on infection and death rates? Is the virus an artificially made bioweapon? Will the vaccine be safe or effective? Will this pandemic ever end?

During each wave of the COVID-19 pandemic, when the state is frantically reconsolidating its power and medical authorities have not yet reached a consensus, paranoia about the virus spirals faster and more widely than the actual virus. The spread of paranoia is not only driven by our psychic anxiety while trapped in mandatory quarantine but also mirrors the irrationality of the crisis of government and the profit-driven model of health care itself, which has always prioritized some lives over others in terms of who accesses a ventilator, gets to be tested, or is able to stay home with a steady income. The state's failure to properly consolidate a "public" in a public health crisis has meant many have been left with death as their only option. This necropolitics heightens the sense of paranoid disillusionment and disfranchisement of the global psyche (Foucault, 2003). Unlike countries such as Taiwan, South Korea, Singapore, and Vietnam that dealt with Severe Acute Respiratory Syndrome (SARS) in 2003, the Western world lacks more recent experience of epidemic crises and has proven to be quite incompetent in containing the virus. In the US, many have drawn comparisons between COVID-19 and the 1980s AIDS epidemic, not only for the latter's contagious and devastating qualities but also the affective response of distrust, fear, and suspicion of the state that has actively spread false information about the queer communities. Paranoia generates conspiracy theories that lead to the further breakdown of social trust on the one hand and show the potential of challenging authority and self-protection out of vulnerability on the other. Thinking through the queer experience in AIDS history in relation to queer theory, this article points to the reparative potentials of conceptualizing paranoia - an affect strongly felt during a time of crisis beyond the binary of health and pathology.

Drawing from the critical interventions of Eve Sedgwick, Melanie Klein, Heather Love, and Silvan Tomkins, I engage with interconnected dialogues across the fields of queer theory, psychoanalysis, and affect theory that refuse to simply reject paranoia and turn towards scientific rationalism but rather pursue the productive capacities of paranoia. I first highlight how the clinical and mainstream scientific approach that seeks to eliminate paranoia is incapable of addressing the defensive need of the wounded psyche, and secondly I draw attention to the limits of critical theory based on paranoid affect that has relied on a political vision of negativity via critique. This article further dispenses with the individualistic, clinical approach to paranoia in psychology in order to move 
toward an affective analysis of the "global psyche" (Béhague and MacLeish, 2020) that takes the world as a focal point of reference and an interpretative frame. From the scale of the virus to cross-national geopolitical conflict, I not only examine how paranoia accumulates and circulates across groups, producing racialized splits in the global psyche, but also highlight the critical possibilities of engaging in a reparative practice of paranoid knowledge production that welcomes surprises, engages with multiplicity, and aspires toward transformative action (Felski, 2012; Sedgwick, 2003; Wiegman, 2014).

\section{Global Psyche and Relational Paranoia}

Psychology has a particular affinity with individualist accounts of paranoia. In clinical terms, paranoia is conceptualized as a symptom frequently associated with schizophrenia, delusional disorder, and borderline and paranoid personality disorder (American Psychiatric Association, 2013). These diagnoses tend to evaluate paranoia as an abnormal outcome of an unstable psyche, whose psychiatric diagnosis has been clinically captured in its central definition as "[a] pervasive and unwarranted mistrust of others" (Vyas and Khan, 2016, p. 9). However, critics of psychiatry have rejected the core assumptions that the paranoid subject's realities are simply false, idiosyncratic, and resolute (Cromby and Harper, 2009; Harper, 2008). As a scientific discipline, psychology's naïve realist stance not only misses the opportunity to provide a more holistic and social account of paranoia but often risks rendering marginalized people's experiences unreal or untruthful (Cromby and Harper, 2009). The overdiagnosis of schizophrenia in African American communities, for instance, especially for those who are categorized under the paranoid subtype (Whaley, 2001), has allowed researchers to trace the racial, cultural, and historical effects of the disease beyond reductionist physiological or genetic explanations (Metzl, 2010).

In an affective approach, paranoia is conceptualized beyond the dualistic framework of either an intra-psychic or a cultural phenomenon. Whereas the intra-psychic account tends to pathologize experiences of paranoia, the cultural analysis of a paranoid position pays little attention to the agency and complexity of a person's subjectivity, let alone the speculative potentials of the imagination (Harper, 2008; Liebert, 2018). Eve Sedgwick (2003) has illustrated how paranoia has become a collective response ingrained in queer communities, scholarship, and activism in response to the AIDS epidemic, where LGBTQ individuals were highly stigmatized and "let die" by the state. The queer habit of paranoia, as well as the anxiety and urgency to forestall any potential dimension of critique, Sedgwick argues, largely arises from the historical trauma and the shared knowledge that the crisis was a result of

deliberate state mismanagement and neglect. Paranoia becomes a defensive 
affect, as Sedgwick writes in following the work of psychoanalyst Melanie Klein (1996), where the paranoid position is marked by a sense of "terrible alertness to the dangers posed by the hateful and envious part-objects that one defensively projects into, carves out of, and ingests from the world around one" (p. 123). The framing of paranoia as a "position" with a certain temporal and spatial range, rather than an internal condition, highlights its relational effects and embeddedness in multiple material and social realities.

Paranoid affect is not an end in itself but rather has the potential to be extended in multiple directions. As the psychologist Silvan Tomkins (1962) has argued, "Any affect may have any 'object" (p. 190), meaning that affect is neither driven by a singular origin nor destined for a singular outcome. Paranoia does not activate or prohibit a behavior (e.g., mistrust or suspicion) but instead adds textual and relational capacity to social experiences (Liu, 2017). In the context of a global pandemic where paranoia is collectively felt, we may rethink the function of paranoia from the clinical position of pathology and absurdity in the direction of a social symptom of our currently shifting lifeworlds and new forms of sociality. As the virus spreads at an unprecedented speed and geographical scale, it reorganizes our perceptions of time and space, challenging the "common sense" world to which we are accustomed and intensifying existing social conflicts and inequalities globally.

Pursuing an affective analysis of the present global psyche (Béhague and MacLeish, 2020) means that the sense of paranoia in crisis should not be reduced to an unrealistic individual account of delusion or a cultural conspiracy that victim-blames a targeted group. From the psychoanalytic traditions, both Freud and Kristeva remind us that the psyche is a discursive product and is embedded within socio-historical developments (see Elliott, 1992). The psyche acts according to a set of social customs, cultural labels and relational practices, and thus cannot simply be examined through clinical expertise under a medical regime but must instead be examined through the global and intimate circulation of concepts, ideas, and discourses. As the dominant affect afflicting the global psyche in times of crisis, paranoia is ultimately relational: an intersubjectively embodied phenomenon that indexes how perceived social influences and surrounding material environments are intimately intertwined with one's own reality and collective memory. While paranoia drives conspiratorial thinking in a way that redirects our attention away from meaningful and democratic dialogues (Latour, 2004), it also has the capacity to act as a preemptive affect for the sake of self-protection as well as a heightened state of social awareness. The approach of "thinking rationally out of paranoia" that has regularly been offered by scientific experts, or subjugating paranoia to the bodies of racialized Others, only produces other forms of harmful paranoia. Departing from this clinical approach, a reparative practice of paranoia entails a twofold analysis of contextualizing the social conditions that enable paranoid 
circulation as well as becoming attentive to the emergent spaces of relational possibility bounded by our shared affect.

\section{Psychic Splitting: Orientalist Conspiracy}

Within a month of the first patient being identified (McNeil, 2020), the United States surpassed China, the origin of the outbreak, in the number of confirmed COVID-19 cases and became the global epicenter of the pandemic, producing an immense sense of loss and despair that has forced us to prepare for the worst. In the midst of this inconceivably traumatic reality, conspiracy has also run rampant. On social media sites, netizens have circulated theories about the questionable origins of the virus as linked to the "Chinese practice" of bateating, laboratory manufacture, biowarfare, $5 \mathrm{G}$ mobile networks, or vaccine propaganda by pharmaceutical companies (see Lee, 2020). In January 2020, when the virus began to spread in Wuhan, China, a Twitter post that speculated upon the connection between the development of $5 \mathrm{G}$ telecom towers and the disease went viral: "Wuhan has 5,000+ \#5G base stations now and 50,000 by 2021 - is it a disease or 5G?” (cited in Satariano and Alba, 2020). This widespread conspiracy claimed that $5 \mathrm{G}$ would damage lung cells and make people more susceptible to the coronavirus, while playing into the global fear of digital surveillance and national security concerns in relation to the Chinese telecom company, Huawei, which has been banned by various countries, including the US and UK to date. While the digital security allegations are probably more plausible than the 5G-linked COVID-19 conspiracy, both are driven by the psychic desire to project the problem outside and frame it as a "foreign threat" based on Orientalist and anti-Communist stereotypes about the Chinese. In this sense, paranoia cannot be read as purely "irrational" but is produced by the material and affective archives of racialized histories in our global psyche, drawing from existing social sources and our existential anxiety to construct a new reality.

The relational nature of paranoia produces what Klein (1996) calls "splitting," where the psychic capacity of experiencing the full scale of emotions and interpersonal perspectives at times of non-crisis is significantly reduced and swallowed by the obsessive object of concern due to conspiratorial thinking. Here, paranoia drives attention away from the insecure self toward an exterior obsessive object (i.e., conspiracy theory) that ends up consuming the self (Cromby and Harper, 2009). While minorities are often framed as paranoid subjects due to the harmful consequences of their endurance of everyday microaggression (Chakraborty and McKenzie, 2002), the paranoid practice of splitting emphasizes the psychological tendency to project problems outside of one's psyche and onto the bodies of the racialized foreign Other. Drawing from Klein, Sedgwick (2003) argues that conspiracy is the outcome of a wounded ego 
splitting itself from the depressive position. When encountering inconceivable loss, the ego splits into two parts - one part protecting the ideal object and the other attacking the bad object - leading to a schizoid position (Klein, 1996; see also Segal, 2018). Refusing to let go of the idealized object, be it the feeling of security or patriotism, one creates and invests in conspiracy - a part-object - to avoid examining the holistic picture of pain and one's active role in the process. Orientalist conspiracy becomes a defense mechanism that refuses to allow for comprehension of the magnitude and severity of the pandemic in order to protect the idealized part-object of Western superiority.

Conspiracy circulates via our selective perception regarding the spread of the virus and the inability to comprehend the totality of the present power structure. Populist sentiments of "good people" against "evil elites" and sinophobic prejudice thus become the easier way out, rather than examining the pandemic as a crisis of global structural inequality (Bergmann, 2018; Schild, 2020). This schizoid conspiracy has come to circulate at a global scale and been used as a form of disciplinary power by the state. The pandemic has become a way for the United States and China to extend their previous trade wars and deflect responsibility for the crisis; for instance, consider when a spokesperson from the Chinese Foreign Ministry accused the US military of possibly bringing the virus to Wuhan (Crossley, 2020), the initial outbreak location, and the way then president Donald Trump fueled already rampant anti-Asian racism by calling COVID-19 the "Chinese virus" (Serwer, 2020). This cultural war of conspiracy has not only failed to address or resolve the pressing humanitarian crisis of the pandemic but has also compromised the safety and dignity of Asians in the diaspora who have been blamed for it, pathologized as contagious viruscarrying bodies, and suffered a surge of pandemic-related hate crimes globally (Lim, 2020). People of East Asian descent in metropoles such as New York City, San Francisco, London, and Paris have reported being spat on, beaten, stabbed, and called "coronavirus" in the streets (Chisholm, 2020; Russell, 2020). The NYPD reported anti-Asian attacks jumped 1,900\% in NYC in 2020, in which more than 2,800 cases were reported (Lang, 2021). These are not isolated events but markers of a cumulative racist fear that has been driven by the historical association between Asian bodies and disease (Wong, 2020). Even the FBI warns that hate crimes against Asian Americans are likely to surge, due to the assumption that "a portion of the US public will associate COVID-19 with China and Asian American populations" (Margolin, 2020). Before the social distancing advisory was announced, as someone of East Asian descent I had already limited my time outside in fear of physical or verbal assaults. On public transit in New York City, whether from my subjective fear or the racial reality, I began to sense people avoiding sitting next to me, which intensified the feeling of an already existing paranoid public. Indeed, paranoia is contagious and distancing. For some, it engenders suspicion of potential harms from others; and for others, it anticipates the repeat of historical trauma. 
These widely shared conspiracies are not only distorted stories but become a public crisis in itself, as people who have endorsed conspiracy theories are less likely to comply with the government's health guidelines (Freeman et al., 2020; Imhoff and Lamberty, 2020; Taylor, 2020). Although, from a scientific and clinical standpoint, the solution to conspiratorial thinking is often to emphasize the effectiveness of evidence-based preventive behaviors such as social distancing, handwashing, and mask-wearing, the paranoid drive cannot be contained by rational thinking alone. Rather, Imhoff and Lamberty (2020) found that people who endorse conspiracies about COVID-19 tend to exhibit more "selfcentered prepping behaviors" such as hoarding goods, withdrawing available cash, and stocking up on food and petrol. Intriguingly, conspiratorial thinking does not indicate a lack of concern or care; to the contrary, conspiracy believers are more likely to prepare for the worst, especially those who think that the virus originated from a laboratory (Imhoff and Lamberty, 2020). What this finding signifies is that conspiracy is not necessarily just a lack of "rationality" but a misplacement of concern toward individualistic goals and aims. Conspiracy is not in opposition to empiricism. Rather, it is a kind of faulty empiricism marked by a partial point of view and confirmation bias. The conspiracy believers - anti-vaxxers, colorblind racists, or those who think the pandemic is a hoax - are all driven by the desire to finding empirical evidence that confirms their specific and partial experiences. Both the conspiratorial and rationalist discourses are paranoid in the sense that they look at power as a relatively dichotomous and zero-sum position - all-or-nothing, with no middle room for error or mistake. These discourses reinforce each other in the search for an "absolute truth" about the virus, and, in lieu of the inevitable uncertainties surrounding the ongoing pandemic, the human fear of the unknown is then projected onto a "foreign object."

In particular, Sedgwick (2011), via Klein's theory of relationality, has warned us about such "all-or-nothing" approaches to agency. The Kleinian subject's perception of the self as either omnipresent or helpless is in fact a frightening position, as the individual's desire is always self-contradictory and at times selfdestructive. For instance, the conspiratorial belief that one has no control over the spread of the virus because it was manufactured by a malicious, powerful Other may produce a parallel process of harmful self-obsession, in which the conspirator believes that they are the only individual who has the correct solution to solve the mysterious crisis while disregarding other people's safety. To think about power as a set of relations rather than an object to be acquired allows us to consider what Sedgwick calls "the middle ranges of agency - the notion that you can be relatively empowered or disempowered without annihilating someone else or being annihilated" (p. 632) and to have a sense of relief from all-consuming paranoia. This perspective on power as a form of relationality makes possible such a middle space between omnipotence and helplessness. The shift away from an individualistic clinical account of the 
psyche toward the framework of the global psyche allows us to see how power unfolds via the complex webs of relations surrounding geopolitical competition, the medical industrial complex, and the racialization of the virus, rather than simply reproducing paranoid discourses of crisis (Béhague and MacLeish, 2020).

\section{Reparative Practice in Time of Crisis}

The paranoia-driven processes of scapegoating the Other and splitting the self from the collective whole have shown their futility and destructiveness at a global scale. At the same time, a purely scientific approach that demonstrates the effectiveness of evidence-based health guidelines seems to be inadequate in repairing the paranoid splitting of the minds of conspiracy believers. Worse, anti-mask protestors and anti-vaxxers have challenged the state's intervention via public health measures as a means to exert further control over their bodies, appropriating the feminist slogan of "My Body, My Choice" in rallies across the US, which has led to further civil unrest and public harm (Bianco, 2020). The current crisis of psychic splitting at multiple levels - geopolitical, national, political, racial, classed, and ecological - requires us to elevate psychoanalytic reading beyond the individual and clinical fixation on mitigating negative affects. In other words, the uncertainty surrounding the pandemic's prognosis inevitably produces paranoia that is unable to be simply contained by our limited "scientific truth."

What we can do as critical scholars is to redirect the analysis of paranoia toward a more generative and collective sociality, moving toward a holistic view of the global psyche. To this end, I propose a twofold reparative practice to comprehend the directional multiplicity of paranoia as well as the unfolding shapes and effects of the global psyche driven by relational affects. This analysis necessitates not only a deep examination of the structural and material processes of the pandemic but also a speculative response to highlight the collective actions generated by the crisis.

The first move of this reparative practice is to treat paranoia as a "strong theory" that can disentangle power relations through a "hermeneutics of suspicion" (Sedgwick, 2003), understood as the practice of critically interrogating an epistemological stance and the interpretative methods employed in the process of knowledge production (p. 124). Utilizing paranoia in an analysis of power is to treat with suspicion the "new normal" of massive layoffs, labor without protection, and social distancing without sociality: a "normality" which disproportionally impacts people with disabilities, service sector workers, racialized communities, the undocumented, women, and queer and transgender people who do not have robust social safety nets. Using paranoia as a strong theory entails questioning the political narrative of "returning to normal" once - 
and if - the pandemic can be mitigated, which overlooks how marginalized communities are expected to absorb the material and affective disinvestments and dispossession of the state in the meantime.

The second move is to refuse psychology's habit of prediction, diagnosis, and control, and instead to build an imaginative and collective response to action. This "weak theory" approach, according to Tomkins (1962), "is capable of accounting for a wide spectrum of phenomena" (p. 433). In contrast to strong theory, weak theory rejects the psychological tendency toward universality and prodromal diagnosis, captures the phenomenological experience of the moment and pries open immanent possibilities for change in our behavior. Whereas paranoia is frequently enacted in the mode of a "strong theory" that attempts to classify, control and anticipate all situations, and strive for generalizability across contexts (Sedgwick, 2003, p. 133; Tomkins, 1962), a reparative practice proceeds as a "weak theory" that is flexible, descriptive, contextual, and phenomenologically open and sensible. It does not aim at prediction but desires pleasure and surprises and maximizes the potential of positive affects (Sedgwick, 2003, p. 136).

Pandemic paranoia has, in fact, not individualized people but radicalized them to create collective responses to the crisis of care and state violence, one example of which is the emergence of self-organized mutual aid groups across the globe, where people form coordinated systems of delivering food and medical supplies, as well as providing emotional and physical support, and virtual spaces (Correal, 2020; Gabert-Doyon, 2020). These organizing efforts grow like an interdependent neurological network that connects isolated nodes and takes over the state's tasks as it fails to address the basic needs of people in crisis. For instance, the scale and intensity of the Black Lives Matter protests in response to unjust police brutality have grown internationally and point toward another possibility for collective change amidst major global crisis by linking the demand for Black lives to state failure and advocating for redistribution of police funding (Noor, 2020). In general, the intensity of the pandemic has forced the majority of the world's people to change their routines, to pause, and readjust their relationship to the world around them and to one another.

Both steps of the reparative practice are crucial: neglecting either one of them would result in further paranoid splitting and political bifurcation of the global psyche. In the case of the surging anti-Asian violence during the pandemic, a critical, paranoid take on the issue risks fixating on the partial experiences of Asian victimization. The fear, anger, and distrust that Asian communities feel often turn into calls for more police force and patrols, as well as charging these attacks as "hate crimes." However, a reparative practice gives us pause to rethink how these feelings of powerlessness may orient us toward a different conception of justice rather than reinforcing the carceral state or inciting a "race war" between Asians and other racial groups. In Anne Anlin Cheng's (2021) writing about this wave of anti-Asian violence, she observes that the "unprocessed grief" of minority groups is turned into the narrative of a single- 
group racial empowerment. However, this often becomes a fixated paranoid position that cannot repair racial relations fundamentally. To the contrary, the position of "racial entanglement" can be the beginning of a reparative practice that aims toward bounded interests and collective survival, "[b]ecause the challenge of democracy is not about identifying with someone like yourself (that's easy to do) nor about giving up your self-interest (that's hard to ask). It's about learning to see your self-interest as profoundly and inevitably entwined with the interests of others" (Cheng, 2021). Only in this way can the paranoid driven "grievance" be loosened, released and gradually processed as reparative "grief" (Cheng, 2000).

\section{Beyond Critique: Feeling the "Good Surprises"}

Klein (1996) has emphasized the importance of the process of reparation for the paranoid-schizoid position, where accepting one's feelings of loss can help integrate the ego as "it makes for an increased understanding of psychic reality and better perception of the external world, as well as for a greater synthesis between inner and external situations" (p. 172). Not only are the two positions - the paranoid and the schizoid - inseparable, but reparation only comes from developing a capacity to accept both positions as a complete object. Drawing from Klein's analysis, Sedgwick (2003) argues that reparative practice is not a rejection or elimination of paranoia but rather an extension from its "rigid relation to temporality" of pursuing all forms of preemptive foreclosure against bad surprises and mistakes, to "glimpse the lineaments of other possibilities" ( $\mathrm{p}$. 146). In other words, paranoia is not entirely unproductive yet requires continual engagement. The point here is certainly not to endorse or accept the aforementioned racialized and disruptive conspiratorial thinking but to understand that paranoid critique and distrust of authorities come from both the political right and left, so that we might move beyond the individualizing solutions that have only aggravated the present crisis. Similarly, Heather Love (2010) argues that it would be incorrect to read Sedgwick's work as only a call for reparative reading. Instead, the paranoid and the reparative are necessarily co-constituting and co-productive, bound together by a shared affect. Love states that the danger of paranoia and reparation is to idealize either analytical position as both are grounded in anxiety (p. 239). Paranoia without reflexivity can easily lead to the current practice of splitting out of our psychic anxiety the contagious vs. the immune, the uncivilized vs. the modern, the authoritarian vs. the democratic, the scientific vs. the conspiratorial - and thus objectifying the splits as actual subjects and communities. In contrast, placing paranoia in the tradition of critical hermeneutics is to interrogate how the dichotomies are reified through global power relations and historical processes. 
To forego the rigid temporality of psychological analysis that is often fixated on the prognosis of a pathology, a reparative practice of "weak theory" asks us to focus on the texture of the presence, or what Sedgwick (2003) calls "thick descriptions" (p. 21). It turns our psychological method from distant diagnosis and prediction to one that closely senses the muddy and entangled relations in the here and now. Informed by Sedgwick, the literary critics Best and Marcus (2009) have proposed two distinctive interpretative methods of "symptomatic reading" and "surface reading": the former focussed on the symbolic, latent, or concealed meanings of the current conditions through a hermeneutics of suspicion; and the latter associated with an attentiveness to the texture, depth, and materiality of the present. The unfolding conflicts of the global psyche as a whole necessitate not only a symptomatic diagnosis and strong critique of its structural inequalities but also a surface attentiveness to the emergent spaces of disruption, refusal, and collective care practice for mutual survivals. The pandemic, then, can be conceptualized as a crisis of global health as well as a crisis of the legitimacy of global authorities - opening up spaces for social changes.

For instance, demonstrators from Hong Kong have taken up mask-wearing to defy police surveillance and tear gas attacks to a point that the Hong Kong state implemented a ban on masks during the height of the Anti-Extradition Law Amendment Bill movement (Anti-ELAB) that defied Beijing's anti-democratic policy in October 2019 but had to mandate mask-wearing in public to control the viral spread of COVID-19 the following year (Pang, 2020). Understanding the effect of masking through a surface reading - as a literal emphasis on the materiality and utility of the masks as an object - is politically effective in that it makes visible the failure and contradiction of the Hong Kong state. Masking falls into what Sedgwick (2011) calls the "the middle ranges of agency" (p. 632) - where Hongkongers negotiate with the multiple meanings of masks - as the state has mandated mask-wearing based on public health concerns yet disproved it during political mobilization. Whereas, in a symptomatic reading of the situation, the mask is a strong political object - in the state's contradictory definitions of the mask as medical in one context and political in another, and in the citizens' active decision whether to wear the mask - a surface reading emphasizes Hongkongers' collective practice in insisting on mask-wearing without necessarily engaging in a direct discursive claim of the mask "for politics" yet making the mask ban basically irrelevant. Resisting the dichotomous categorization of the masks as either a political or a medical object, the surface of the mask emerges in the context of the pandemic, literally and figuratively, as what Love (2010) calls "good surprises" (p. 239).

The twofold practice of both deep analysis/strong theory/symptomatic reading and imaginative response/weak theory/surface reading is where we find paranoia as an affect that involves a reparative impulse. Rather than "combating" the virus, as if it is a singular event in history that can be diagnosed 
and eradicated, we must realize that we have lived and always will live interdependently vis-à-vis its various mutations and the potentials of its movement. Zoonotic contagion works by physical contact and transformation through contact, in which the pathogen jumps from one species to another kind through regular contact and evolves by adapting to new hosts. This transmission transforms both the capacity of the virus and its host. The widespread call for "social distancing" is a form of effective reparative paranoia - it asks us to change our behaviors as if we are already the carriers of the virus to protect those who are immunocompromised and at a higher risk around us, rather than assuming the binary positions of the infected vs. the uninfected. Reparative practice rejects the diagnostic mentality but utilizes preemption as a strategy to ensure the function of a social whole. Only in this way will we feel the urgency to move beyond the destructive patterns of privatization, pathologization, and militarization, as well as the paranoid tendency of splitting, conspiracy, and suspicion, that are inadequate reactive responses from the limited perspectives of our partial experiences. Through an expanded reading of paranoia, we may continue engaging in collective practices of locating structural violence, disseminating care, building interdependent interests, and reattaching the fragmented self to the entirety of the global psyche.

\section{Acknowledgements}

I would like to thank the two anonymous reviewers for their careful reading and productive comments that were critical for the revisions of this article.

\section{About the Author}

Wen Liu is Assistant Research Fellow at the Institute of Ethnology, Academia Sinica, Taiwan. She has focused her research on the engagement between the affective turn, queer theory, and critical psychology. Her writing has been published in journals such as American Quarterly, Feminism \& Psychology, Journal of Asian American Studies, and Subjectivity.

\section{References}

American Psychiatrist Association (2013) American Psychiatric Association: Diagnostic and Statistical Manual of Mental Disorders: Diagnostic and Statistical Manual of Mental Disorders. 5th edn. Arlington, VA: American Psychiatric Association.

Béhague, D.P. and MacLeish, K. (2020) The global psyche: Experiments in the ethics and politics of mental life. Medical Anthropology Quarterly 34(1): 5-20. 
Bergmann, E. (2018) Conspiracy \& Populism: The Politics of Misinformation. Switzerland: Palgrave Macmillan.

Best, S. and Marcus, S. (2009) Surface reading: An introduction. Representations 108(1): $1-21$.

Bianco, M. (2020) COVID-19 mask mandates in Wisconsin and elsewhere spark "my body, my Choice” hypocrisy. NBC News, 3 August. https:/www.nbcnews.com/think/opinion/ covid-19-mask-mandates-wisconsin-elsewhere-spark-my-body-my-ncna1235535, accessed 9 September 2021.

Budryk, Z. (2020) Fauci: "If it looks like you're overreacting, you're probably doing the right thing." The Hill, 15 March. https://thehill.com/homenews/sunday-talk-shows/ 487639-fauci-if-it-looks-like-youre-overreacting-youre-probably-doing-the, accessed 9 September 2021.

Chakraborty, A. and McKenzie, K. (2002) Does racial discrimination cause mental illness? British Journal of Psychiatry 180: 475-7.

Cheng, A.A. (2000) The Melancholy of Race: Psychoanalysis, Assimilation, and Hidden Grief. New York: Oxford University Press.

Cheng, A.A. (2021) "What This Wave of Anti-Asian Violence Reveals About America." The New York Times, 21 February. https://www.nytimes.com/2021/02/21/opinion/antiasian-violence.html, accessed 9 September 2021.

Chisholm, N.J. (2020) Asian Americans report hundreds of racist incidents in less than two weeks. Colorlines, 27 March. https://www.colorlines.com/articles/asian-americansreport-hundreds-racist-incidents-less-two-weeks? fbclid= IwAR1M5Mo9olyOLCEIBVz0TkL6D9y8-pD1iGqqNQaAV26nB74ksFPW9cQloTc, accessed 9 September 2021.

Correal, A. (2020) The complicated calculus of helping neighbors during a pandemic. The New York Times, 24 March. https://www.nytimes.com/2020/03/24/nyregion/nycoronavirus-help.html, accessed 9 September 2021.

Cromby, J. and Harper, D. (2009) Paranoia: A social account. Theory \& Psychology 19(3): 335-61.

Crossley, G. (2020) China government spokesman says U.S. military may have brought virus to China. U.S. News, 12 March. https://www.usnews.com/news/world/articles/ 2020-03-12/china-says-immoral-and-irresponsible-us-officials-shift-coronavirus-blame, accessed 9 September 2021.

Elliott, A. (1992) Social Theory and Psychoanalysis in Transition: Self and Society from Freud to Kristeva. New York: Routledge.

Felski, R. (2012) Critique and the hermeneutics of suspicion. M/C Journal 15(1), online publication, doi:https://doi.org/10.5204/mcj.431.

Foucault, M. (2003) "Society Must Be Defended": Lectures at the Collège de France 1975-1976. Edited by M. Bertani and A. Fontana. Translated by D. Macey. New York: Picado.

Freeman, D., Waite, F., Rosebrock, L., Petit, A., Causier, C., East, A., Jenner, L., Teale, A., Carr, L., Mulhall, S., Bold, E., and Lambe, S. (2020) Coronavirus conspiracy beliefs, mistrust, and compliance with government guidelines in England. Psychological Medicine 1-30, online publication 19 May, doi: https://doi.org/10.1017/ S0033291720001890.

Gabert-Doyon, J. (2020) Paranoia and the coronavirus: How Eve Sedgwick's affect theory persists through quarantine and self-isolation. Verso, 17 March. https://www. 
versobooks.com/blogs/4597-paranoia-and-the-coronavirus-how-eve-sedgwick-s-affecttheory-persists-through-quarantine-and-self-isolation, accessed 9 September 2021.

Harper, D. (2008) The politics of paranoia: paranoid positioning and conspiratorial narratives in the surveillance society. Surveillance \& Society 5(1): 1-32.

Imhoff, R. and Lamberty, P. (2020) A bioweapon or a hoax? The link between distinct conspiracy beliefs about the Coronavirus disease (COVID-19) outbreak and pandemic behavior. Social Psychological and Personality Science 11(8): 1110-18.

Klein, M. (1996) Notes on some schizoid mechanisms. The Journal of Psychotherapy Practice and Research 5(2): 160-79.

Lang, C. (2021) "Hate crimes against Asian Americans are on the rise. Many say more policing isn't the answer. Time Magazine, 18 February. https://time.com/5938482/ asian-american-attacks/, accessed 9 September 2021.

Latour, B. (2004) Why has critique run out of steam? From matters of fact to matters of concern. Critical Inquiry 30: 225-48.

Lee, B. (2020) No, COVID-19 coronavirus was not bioengineered. Here's the research that debunks that idea. Forbes, 17 March. https://www.forbes.com/sites/brucelee/2020/03/ 17/covid-19-coronavirus-did-not-come-from-a-lab-study-shows-natural-origins/ \#163b98c3728c, accessed 9 September 2021.

Liebert, R.J. (2018) Psycurity: Colonialism, Paranoia, and the War on Imagination. New York: Routledge.

Lim, D. (2020) Coronavirus discrimination: Victims share stories of hate crimes after 650+ incidents reported. $A B C 7$ News, 27 March. https://abc7news.com/coronavirusdiscrimination-650+-incidents-of-hate-crimes-reported-online/6054466/, accessed 9 September 2021.

Liu, W. (2017) Toward a queer psychology of affect: Restarting from shameful places. Subjectivity 10(1): 44-62.

Love, H. (2010) Truth and consequences: On paranoid reading and reparative reading. Criticism 52(2): 235-41.

Margolin, J. (2020) FBI warns of potential surge in hate crimes against Asian Americans amid coronavirus. ABC News, 27 March. https://abcnews.go.com/US/fbi-warnspotential-surge-hate-crimes-asian-americans/story? $\mathrm{id}=69831920 \& \mathrm{fbclid}=$ IwAR2SdLPbeUeUpRfgsSIbc0DUiRZmVMkfnrSTg2Wnk_CnPWFJxEfBRMHTvIM, accessed 9 September 2021.

McNeil Jr., D.G. (2020) The U.S. now leads the world in confirmed coronavirus cases. The New York Times, 26 March. https://www.nytimes.com/2020/03/26/health/usacoronavirus-cases.html, accessed 9 September 2021.

Metzl, J.M. (2010) The Protest Psychosis: How Schizophrenia Became a Black Disease. Boston, MA: Beacon Press.

Noor, P. (2020) What the George Floyd protests have achieved in just two weeks. The Guardian, 8 June. https://www.theguardian.com/us-news/2020/jun/08/what-haveprotests-achieved-george-floyd-death-police-funding-statues, accessed 9 September 2021.

Pang, J. (2020) Hong Kong court rules that blanket ban on masks is unconstitutional. Reuters, 9 April. https://www.reuters.com/article/us-hongkong-protests-masksidUSKCN21R193, accessed 9 September 2021. 
Russell, A. (2020) The rise of coronavirus hate crime. The New Yorker, 17 March. https:// www.newyorker.com/news/letter-from-the-uk/the-rise-of-coronavirus-hate-crimes, accessed 9 September 2021.

Satariano, A. and Alba, D. (2020) Burning cell towers, out of baseless fear they spread the virus. The New York Times, 11 April. https://www.nytimes.com/2020/04/10/ technology/coronavirus-5g-uk.html

Schild, L., Ling, C., Blackburn, J., Stringhini, G., Zhang, Y., and Zannettou, S. (2020) "Go eat a bat, Chang!": An early look on the emergence of sinophobic behavior on web communities in the face of COVID-19. arXiv, advance online publication. http://arXiv: 2004.04046.

Sedgwick, E.K. (2003) Touching Feeling: Affect, Pedagogy, Performativity. Durham and London: Duke University Press.

Sedgwick, E.K. (2011) Melanie Klein and the difference affect makes. In: J. Halley and A. Parker (eds.) After Sex? On Writing Since Queer Theory. Durham and London: Duke University Press, pp. 283-302.

Segal, H. (2018) Introduction to the Work of Melanie Klein. New York: Routledge.

Serwer, A. (2020) Trump is inciting a coronavirus culture war to save himself. The Atlantic, 24 March. https://www.theatlantic.com/ideas/archive/2020/03/trump-is-the-chinesegovernments-most-useful-idiot/608638/, accessed 9 September 2021.

Taylor, J. (2020) Bat soup, dodgy cures and 'diseasology': the spread of coronavirus misinformation. The Guardian, 31 January. https:/www.theguardian.com/world/2020/ jan/31/bat-soup-dodgy-cures-and-diseasology-the-spread-of-coronavirus-bunkum, accessed 9 September 2021.

Tomkins, S.S. (1962) Affect, Imagery, Consciousness: Vol. II: The Negative Affect. New York: Springer.

Vyas, A. and Khan, M. (2016) Paranoid personality disorder. American Journal of Psychiatry Residents' Journal 11(01): 9-11.

Whaley, A.L. (2001) Cultural mistrust and the clinical diagnosis of paranoid schizophrenia in African American patients. Journal of Psychopathology and Behavioral Assessment 23(2): 93-100.

Wiegman, R. (2014) The times we're in: Queer feminist criticism and the reparative 'turn'. Feminist Theory 15(1): 4-25.

Wong, E.H.S. (2020) When a disease is racialized. Briarpath Magazine, 3 February. https:// briarpatchmagazine.com/articles/view/when-a-disease-is-racialized-coronavirus-antichinese-racism, accessed 9 September 2021.

Publisher's Note Springer Nature remains neutral with regard to jurisdictional claims in published maps and institutional affiliations. 